\title{
Broad Working Approaches in Yoga and Physiotherapy
}

\author{
Mukund Vinayak Bhole* \\ Member of the Board of Studies in Basic Medical Sciences, Pune University, India
}

Submission: October 19, 2016; Published: October 22, 2016

*Corresponding author: Mukund Vinayak Bhole, 16Badrivishal Society, Tungarli, P.O.-Kaivalyadhama, Lonavala (Dist.-Pune), Maharashtra 410403, India.

\section{Opinion}

It is heartening to note that Juniper Publishers have launched the publication of the 'Journal of Yoga and Physiotherapy' to cover and contribute in two more health related areas. Physiotherapy is an offshoot of modern (western) medical sciences while Yoga is one of the six orthodox systems of perceptions belonging to the ancient Indian culture and civilization.

Over a period of time, physiotherapy has developed as a specialty and super-specialty in modern medical education and services. Rehabilitation and vocational training and education as well as crania-sacral therapy are also developing as important disciplines along with physiotherapy. As the name suggests, physiotherapy aims at working with the physical body.

Traditional Yoga education system aims at working with sensing, monitoring and modifying various external and internal environmental and psycho-physiological input factors, events and happenings that contribute in developing awareness of 'self' and to develop an ability to get into and be in some kind of 'transcendental state of awareness' as a part of regular life style. Most of the prevalent National Education Systems aim at objective type of education useful for running administration, business, profession, industry and fulfilling various defense requirements which go on changing from time to time.
In recent times, physiotherapists have started to understand the approaches followed in traditional yoga education and they are trying to integrate some of the principles in their discipline. On the other hand, modern yoga experts are getting exposed to the guidelines followed in physiotherapy and they are trying to develop the physical aspect of yoga on the lines of exercise and sports physiology.

Some hospitals are establishing Yoga Therapy Departments with Yoga Therapists. Medical institutions are taking up clinical research projects. Articles are being published in indexed journals. We come across frequent studies based on Meta analysis in yoga research with specific topic. Most of the research studies in this field can be classified under phase three of clinical research studies. There are relatively very few studies capable of being classified under phase one and two.

There is growing tendency to expect and present subjectively experienced yoga in an objectively verifiable language using parameters which could be studied in laboratory conditions. It is felt that this trend and approach may not be able to do full justice to the age old science and discipline of yoga whose main area of investigation, study and understanding is the nature of the 'self awareness'. 


Your next submission with JuniperPublishers
will reach you the below assets
- Quality Editorial service
- Swift Peer Review
- Reprints availability
- E-prints Service
- Manuscript Podcast for convenient understanding
- Global attainment for your research
- Manuscript accessibility in different formats
( Pdf, E-pub, Full Text, Audio)
- Unceasing customer service
Track the below URL for one-step submission
http://juniperpublishers.com/online-submission.php

